\title{
Kamusal-Özel Alan Ayrışmasının İnşa Süreci ve Sosyal Medya
}

\author{
Osman ALACAHAN ${ }^{1}$ ve Saniye VATANDAŞ ${ }^{2}$ \\ $\ddot{\mathrm{O} z}$
}

"Kamusal alan” ve "özel alan”, Batı Avrupa toplumlarının sosyal ve siyasal koşullarında oluşmuş ve yine bu bağlamda anlam kazanmış birbiriyle ilişikli iki farklı olguyu ifade etmektedir. Bu iki olgunun karşılıklı birbirini inşa edici özelliği, birini anlamak için diğerini dikkate almayı gerekli kılmaktadır. Son yüzyıl dikkate alındığında 'güvenlik', 'ortak yarar' gibi gerekçeler nedeniyle her geçen gün kamusal alanı daha genişlerken, özel hayat alanı ise sürekli daralmıştır. İnternet teknolojisinin gelişme evresi dikkate alındığında ise bireyle, bireyin yaşam alanıyla ilişikli olan özel alan her gün biraz daha bir gözetim nesnesine dönüşerek daralmaktadır. Üstelik özel hayat alanının gittikçe daha çok gözetim nesnesine dönüşümü, önceleri olduğu gibi tamamen dişsal bir iradenin müdahalesi ile değil, bireylerin bizzat kendi istek ve çabalarıyla gerçekleşmektedir. Bireyler kişisel olan ve mahrem kabul ettikleri tüm özelliklerini neredeyse ayrım gözetmeksizin herkesin ilgi ve bilgisine sunarak alenileştirmekte ve üstelik alışılagelmişe aykırı bir şekilde bundan dolayı da memnun olmaktadırlar. Bu inceleme kamusal/özel alan literatürünün taranmasına dayanmaktadır. Bu bağlamda kamusal ve özel alan kavramlarının inşa süreci incelenmiş, takiben genel olarak iletişim teknolojileri özellikle de sosyal medya üzerinden özel alanın gözetim nesnesine dönüşerek daralması incelenmiştir.

Anabtar Kelimeler: Kamusal alan, Özel alan, Sosyal medya

\section{Construction Process of Public-Private Space Separation and Social Media}

\begin{abstract}
"Public space" and "private space" refer to two interrelated phenomena that have formed in the social and political conditions of Western European societies and have gained meaning in this context. The mutually constructive feature of these two facts makes it necessary to consider the other in order to understand one. Considering the last century, while the public space has been expanding day by day due to reasons such as "security" and "common benefit", the private life space has been narrowed constantly. Considering the development stage of the internet technology, the private area associated with the individual's living space is shrinking by becoming a surveillance object every day. Moreover, the transformation of the private life space into more and more surveillance objects is realized by the individual's own wishes and efforts. Individuals publicize all their personal and confidential characteristics by presenting them to everyone's attention and knowledge almost without discrimination. This review is based on the literature review of public/private area. In this context, the construction process of the concepts of public and private space has been examined. Following this, the narrowing of the private area by transforming it into a surveillance object over communication technologies and especially social media was examined.
\end{abstract}

Key Words: Public space, Private space, Social media

\section{Atıf İçin / Please Cite As:}

Alacahan, O. ve Vatandaş, S. (2021). Kamusal-özel alan ayrışmasının inşa süreci ve sosyal medya. Manas Sosyal Araştırmalar Dergisi, 10(1), 720-733.

Geliş Tarihi / Received Date: 30.06.2020

Kabul Tarihi / Accepted Date: 22.10.2020

\footnotetext{
${ }^{1}$ Doç. Dr. - Sivas Cumhuriyet Üniversitesi, İktisadi ve İdari Bilimler Fakültesi, oalacahan@cumhuriyet.edu.tr

(iD) ORCID: 0000-0002-8715-5325

2 Dr. Öğretim Görevlisi - Isparta Uygulamalı Bilimler Üniversitesi, saniyevatandas@isparta.edu.tr

(iD ORCID: 0000-0002-3646-9232
} 


\section{Giriş}

'Kamu', 'kamusal' veya 'kamusal alan', Batı Avrupa toplumlarının sosyal ve siyasal şartlarının ürünü olarak doğmuştur. 17. yüzyılda başlayan fakat asıl formuna 18. yüzyılda kavuşan sosyal ve siyasal koşullar, kamu kavramının inşasını oluşturmuş, takip eden süreçte kavramsal inşa kesintisiz devam etmiştir. Fakat bu durum, 'kamu' ve türevi olguların tamamılla modern zamanlara özgü olduğunu düşündürmemelidir. 'Kamu” sözcüğü eksenindeki kavramsal inşanın başlangıcı çok daha eskilere gitmektedir. Özellikle siyasal süreç içinde yurttaşlar arasındaki etkileşimin rolüne ve önemine işaret eden bir kavram olarak kamusal alanın kökenleri Antik Yunan'a dek gerilere uzanmaktadır. Helenist toplum yapısında egemen olan yaşam tarzı ve toplumsal ilişkiler kendi içinde yapısal ve işlevsel bir ayrışmaya yol açmıştır. Bu durum Aristoteles'in dikkatini çekmiş ve oluşan toplumsal olguda bireyin kendi özelinde şekillenen ve bedeniyle de ilintili olan yaşamı 'ev' ya da güncel tanımla özel alan; özellikle siyaset yaşamının gerektirdiği zorunlu toplumsal ilişkilerin kurulduğu alan olan theoria yaşamını ise 'polis' ile ya da güncel tanımla kamusal alan ekseninde tasnif ederek anlatmıştır. Eğer konuyu tamamılla 'kamu' ekseninde irdelemek gerekirse, Antik Yunan'daki agoralarda ya da kolonyal dönem şehirlerinin tartışma salonlarında gerçekleşen politik idealler ve düşünce alsşverişleri 'kamu'nun inşasında başlangıcı oluşturmuştur. Fakat modern anlamıyla ve işleviyle kamusal alan 18. yüzyll Batı Avrupa’sının sosyal ve siyasal ortamının bir ürünü olarak ortaya çıkmıştır.

Kapitalist sistemin gerektirdiği yeni düzen modern kamusal alanın doğuşuna zemin hazırlamıştır. 18. yüzyıl koşullarında kahvehaneler, kulüpler, salonlar, basın ve parlamento benzeri yerlerde gerçekleşen edebi konular edebi kamusal alanın, söz konusu tartışmaların giderek siyasal konuları da içermesiyle politik kamusal alanın doğuşu gerçekleşmiştir. Kahvehaneler başta olmak üzere benzeri diğer yerlerde yapılan tartışmalar yazılı basın endüstrisinin gelişmesiyle birlikte daha da güçlenmiş ve giderek basın, devlet otoritesinin etkinlik ve uygulamalarına yönelik siyasal eleştirilerin ve tartışmaların yapıldığı, yorumların üretildiği temel forum haline gelmiştir. Böylelikle uzun bir süre kamusal alanın temel iletişim araçlarını gazeteler ve dergiler oluşturmuştur. Bu süreçte ve söz konusu araçlar sayesinde öncelikle, kamusal alan olgusu için temel niteliğe sahip olan devletin dışında siyasal iletişimin gerçekleşebileceği sivil bir alan ve bu alana siyasal katılımı mümkün kılacak özne konumlarının oluşumu gerçekleşmiştir. Kamusal katılım ve iletişimi herkesin özgür ve eşit katılımına açık kılacak düşünsel gelişmelerin ve yasal düzenlemelerin meydana gelmesi ise kamusal alanın gelişimini hem hızlandırmış hem de güçlendirmiştir. Tüm bunların arkasındaki temel motivasyon unsuru ise kapitalizmin yol açtığ1 yeni üretim düzeninde ortaya ç1kan modern devlet ile ondan bağımsızlaşan toplumun ürünü olan kamusal ve özel alan ayrımındaki kutuplaşma olmuştur. Bilişim ve iletişim teknolojilerinin gelişime koşut kamusal alan olgusu anlamsal ve işlevsel açıdan sürekli değişime uğramış ve günümüz itibarıyla en kapsamlı konumuna erişmiştir.

'Özel alan’ olgusunun oluşumu, 'kamusal alan’ kavramının oluşumundan bağımsız değildir. Çünkü birinin varlığı diğerinin varlığını zorunlu kılmaktadır. Dolayısıyla modern anlam ve işleviyle kamusal alan 18. yüzyllın ürünü olduğu gibi, özel alan da aynı dönemin şartlarının bir ürünüdür. En genel anlamıyla ifade etmek gerekirse, kamusal sözcügü herkesin denetimine açık olan anlamına gelirken, "özel” sözcügü ise kişinin ailesi ve arkadaşları ile sınırlanan, dışarıya kapalı bir yaşam bölgesini, bir diğer ifadeyle mahremiyet alanına karşılık gelmektedir. Bilişim ve iletişim teknolojilerinin gelişimi kamusal alanı olduğu gibi özel alanı da radikal şekilde değişime uğratmış ve söz konusu değişim süreci halâ olanca hızıyla devam etmektedir. Değişim kamusal alanın lehine, özel alanın aleyhine işlemektedir. Gerçekleşen değişimi özel alan ekseninde irdelemek gerekirse, genel olarak internet teknolojisi, özel olarak da sosyal medya özel alana ait olanlar1 alenileştirerek, özel alan ile ilgili bu unsurları kamunun ilgi ve bilgisine sunarken özel alanın da her geçen gün daraltmasına yol açmaktadır. Ancak önemli olan bu değişimin eskiden olduğu gibi dışsal bir müdahale ile gerçekleşmemesidir. Bireyler söz konusu alenileşmenin öznesidirler. Özneliklerini nesneleşmenin arac1 olarak kullanmaktadırlar. Kısacası bireyler bu süreçte kendi özneliklerini kamusal alanda nesne haline getirmektedirler.

\section{Kamusal Alan}

'Kamu’, Türkçe sözlükte “1. Hep, bütün, 2. Bir ülkedeki halkın bütünü” (Türkçe Sözlük, 1983, s. 633) anlamlarına gelmektedir. 'Kamu alanı' ise sosyo-politik kullanımlardaki anlamıla; "kamu otoritesinin geçerli olduğu yer", "çoğulculuğun, renkliliğin ve özgürlüğün olduğu alan”, "kamu görevlisinin bulunduğu her yer" olarak karşıslık bulmaktadır (Yükselbaba, 2008, s. 227). Biraz daha detaylandırmak gerekirse, 'kamusal alan', İletişim Sözlüğü'nde, Habermas'in The Public Sphere: An Encylopedia Article (Habermas, 1974) yazısına atıfla "sosyo-politik veya pratik sorunların çözülmesi amacıyla kişiler arasında değerler ve ölçümler 
üzerinde mutabakata varılma olanağının bulunduğu kamusal yaşam alanı” (Mutlu, 2004, s. 164, 165) şeklinde tanımlanmaktadır. Bunların yanı sıra, kamusal alan açıklanırken, liberal siyasal düzenin feodal düzenin yerini almaya başladığı 17. ve 18. yüzyıldaki bireylerin toplulukla ilgili sorunları ve konuları tartışmak üzere bir araya geldikleri 'arena'ya atıfta bulunulmuştur (Mutlu, 2004, s. 164). Konuyu detaylı olarak ele almış bulunan Habermas'ın kamusal alan ile ilgili literatürde çoğu zaman atıfta bulunulan önemli tespiti şöyledir:

"Kamusal alan kavramıyla, her şeyden önce, toplumsal yaşamımız içinde, kamuoyuna benzer bir şeyin oluşturulabildiği bir alanı kastederiz. Bu alana tüm yurttaşların erişmesi garanti altına alınmıştır... Yurttaşlar ancak, genel yarara ilişsin meseleler hakkında kısıtlanmamış bir tarzda, yani toplanma, örgütlenme, kanaatlerini ifade etme ve yayınlama özgürlükleri garantilenmiş olarak tartışabildiklerinde kamusal bir gövde biçiminde davranmış olurlar”" (Habermas, 2005, s. 95).

Habermas, 'kamu' ve 'kamusal alan' sözcüklerinin etimolojisinin, toplumsal ve tarihsel bir tahlil için açıklayıc1 olduğunu düşünmüştür. Onun tespitlerine göre Almancadaki 'öffentlichkeit' sözcüğü, 18. yüzyılda 'publicitê' ve 'publicity' ile benzerlik kurularak türetilmiştir. 'Öffentlichkeit', İngilizcedeki 'public sphere’i kapsamakla birlikte, onu aşan bir anlama sahiptir. Yine Habermas’a göre 'öffentlichkeit' sözcügü mekânsal bir anlama sahiptir: "Anlamların geliştirildiği, dağıtıldığı ve üzerinde tartışarak anlaşmaya varıldığı toplumsal alan ya da arenalara ve aynı zamanda bu süreç tarafindan ve bu süreç içinde oluşturulan kolektif gövdeye; 'kamu'ya işaret eder. Ama öffentlichkeit aynı zamanda 'tasavvur edilen bir muhteva ve kıstas' içeriğine de sahiptir” (Yükselbaba, 2008, s. 68). Söz konusu kıstasin Almancadaki kökü 'öffen’ olup, 'açıklık' anlamındadır. Almanya'da 18. yüzyılın sonunda kullanılmaya başlayan öffentlichkeit sözcüğü, bu dönemde bir ihtiyaca denk düştüğü için günlük dilde yer bulmuştur. Mal mübadelesi ve emeğin toplumsallaşması ile kurumlaşan 'burjuva toplumunun' bir unsurudur (Habermas, 2005, s. 59).

18. yüzyıl şartlarındaki anlayışa göre 'politik olan şey', doğal durumlarında kanunsuzluk hâlinde yaşayan insanların bir sözleşme ile haklarını iktidara devrettikleri ve iktidar gücünün aleyhlerine dönmesini önlemek için de iktidarı sınırlayan yasalar oluşturdukları anlayışını dile getiren sözleşmeci kuramlarda temel bulan klasik liberal devlet düşüncesi ve 'genel yarar', 'ortak çıar' fikirleriyle örtüşmeye başlanmıştı. 'Genel yarar adına tartısmak' şeklinde anlaşılmış olan politik olma durumu, zaman içerisine evrilerek, 19. yüzyılın ortalarında, 'genel yarar adına' hareket edecekleri seçmek biçimine dönüşmüştür. Liberal nitelikteki politik anlayışın burjuvanın soylulara karşı yürüttügü mücadelenin ulaştığı zafer ile ortaya çıkan formu esas alındığında; dönemin 'ortak çıkar'ının aslında burjuvanın, hatta eğitimli ve erkek burjuvanın çıkarı olduğu görüşüne ulaşmakta zorlanılmaz. 19. yüzyıl ortalarında kamusal alan anlayışının uzun bir zamandan beri evrilmesinin doğal istikameti doğrultusunda burjuvayla ilişikli sınırlarını aşması ve kitle iletişim araçlarının da yayginlaşmasıyla, 'politik olan' bundan böyle haberleri okumak ve seçimlere katılmak ile eş tutulmaya başlanmıştır. Artık, kamusal olan, 'akılcı tartışmalara girmek' değil 'kamunun bilgilendirilmesi' olarak anlaşılmaktadır (Malkoç, 2018, s. 15).

Kamusal alan olgusu yapısal açıdan ve kavram düzeyinde zaman içinde sürekli değişerek bugünkü formunu kazanmıştır. Habermas'ın Kamusallığm Yapısal Dönüş̧їmü adlı ünlü eserinde dile getirdiği kamusal alanın yapısal dönüşümü ile ilgili tespitleri şu şekilde özetlenmiştir:

“Özel alan ile kamu otoritesinin birbirinden ayrıldığı bir dönemde (17. yüzyllın sonundan itibaren), bireylerin burjuva ve insan olarak, görece eşit biçimde, önce yazınsal konularda, sonra siyasal basının devreye girmesiyle toplumla ve devletle ilgili konularda serbestçe rasyonel-eleştirel tartışmalar yaptıkları, ilkece herkesçe erişilebilir kamusal alandan, devletim özel alana müdahale ettiği, toplumun da devlete nüfuzuyla toplumun "yeniden feodalleştiği”, özel-kamu ayrımının silindiği, reklamların ve halkla ilişkilerin yükseldiği bir dönemde (19. yüzyllın ikinci yarısından itibaren), politik partilerin ve kitle iletişim araçlarının biçimlendirdiği (güdüp yönlendirilen "kitle"den oluşan) "görünüşteki" kamusal alana geçilir" (Kejanlıoğlu, 2004, s. 690).

Kamusal alan sözcügünün modern dönemde adının duyulması, ilk olarak Avrupa bölgesindeki despotik devletlere karşı yürütülen mücadeleler sırasında olmuştur. Kamudan söz etmek, keyfi hareket ettikleri, ellerindeki güçleri kötüye kullandıkları ve kendi 'özel’ çıkarlarını toplumun aleyhine olabilecek şekilde gözettikleri için kuşku duyulan kralları ve kraliyet ailelerini hedef almak anlamına geliyordu (Keane, 2002, s. 296). 'Kamu', 'kamusal erdem', 'kamuoyu’ gibi sözcükler 'basın özgürlüğünü’ ve diğer kamusal özgürlükleri desteklemek için kullanılmıştı. 'Kamu' sözcügünü İngilizcedeki bilinen ilk kullanımı 'kamuyu toplumun ortak çıarı ile bir tutmak' şeklindeydi. John Keane konu ile ilgili bazı tespitleri şöyledir: 
"[D]aha önce tek başlarına hareket eden iki ya da daha fazla kişi hem kendi etkileşimlerini hem de içinde daima ve hâlihazırda konumlandırıldıkları daha geniş toplumsal ve siyasal iktidar ilişkilerini sorgulamak için bir araya geldiklerinde kamusal alan oluşmaya başlamışır. Bu özerk oluşum aracilığıyla kamusal alanın üyeleri yaptıkları şeyleri değerlendirirler, nasıl bir arada yasayacaklarını kararlaştırırlar ve ellerindeki araçların tahmini sınırllıkları içinde öngörülebilir bir gelecekte nasıl ortaklaşa hareket edebileceklerini belirlerler" (Keane, 1984, s. 34).

Habermas'ın, yaptığı kamusal alan tanımlamasında, başka bir deyişle kavramsallaştırmasında öne çıkan özellikler; 'herkese açık olma', 'toplumun bireylerine karşı sorumlu olma, siyasal denetim', 'ortak çıkar' gibi noktalarda toplanmaktadır. Konuya farklı açılardan yaklaşan Arendt'e göre ise kamusal alan teriminde iki farklı anlam yer almaktadır; bunlardan birisi 'alenileşme' ve diğeri ise 'ortaklaşa sahip olunan dünya' anlamlarıdır. Alenileşme anlamındaki kamusal alan fikri, "kamuda gözüken her şey herkes tarafindan görülebilir ve duyulabilirdir ve mümkün olan en geniş açıllı̆̆a sahiptir" (Arendt, 2006, s. 92) anlamındadır. Arendt'in bu sözcüğe yüklediği diğer anlam ise, "hepimiz için ortak olan bir dünya"yı ifade etmektedir. Ancak bu dünya, insanların üzerinde hareket ettikleri sınırlı bir mekânı ve organik yaşamın genel durumunu oluşturan yeryüzü ya da doğayla aynı değildir. Daha çok, insan eseri bir dünyada birlikte yaşayanlar arasında olup biten hususlarda olduğu kadar, insan elinden çıkma şeylerle, insanî yapiyla ilintilidir (Arendt, 2006, s. 95). Bu ise Arendt'in kamusal olana ilişkin düşünce ve tespitleri ile kültür arasında güçlü bir ilişki bulduğunu göstermektedir. Arendt, siyasi olan ile kamusal olanı aynı görmüştür. Ona göre, insanın kendi siyasi bilincini geliştirmesi diğer insanların varlığına, yani insani çoğulluğa bağlıdır (Onat, 2010, s. 11).

Kamusal sözcügünün güncel dildeki yaygın kullanım anlamlarına gelince, dört farklı fakat birbirine oldukça yakın anlamlı kullanım şekli tespit edilebilmektedir (Gripsrud, Hallvard vd, 2010, s. 14):

Illk olarak, kamusal denildiğinde kent meydanları, parklar gibi fiziksel alanların paylaşılan 'ortak'ın (common) kısmına ya da tamamına açık olduğu zaman kamusallıktan bahsediliyor demektir. Bu metafor genişletilirse, malûmat (information) ve kültürel kaynaklar serbestçe erişilebilir ve iletilebilir olduklarında, dolayısıyla potansiyel olarak 'ortak' olana ait (common) olduklarında, kamusala ilişkin düşünülmüş olunur.

İkinci anlamında ise kamusal ve özel arasındaki ayrımdan bahsedilebilir. Kamusal denildiğinde, siyasi birimin bütün üyelerinin ortak çıarı olan konuları, dolayısıyla yönetimsel kurumların meşruiyetine ilişkin konular tanımlanmaktadır. 'Özel' denildiğinde ise insanların özel hayatına ve kişisel sırlarına bırakılması gereken yaşam alanları tanımlanmaktadır. Fakat kamusal ve özel arasındaki ayrım sabit ve belirgin değildir. Aksine, kamusal ile özel alan arasındaki sınırın nereden çizileceği konusu demokratik toplumlarda devam eden bir ihtilaftrr.

Üçüncü olarak, kamusal sözcügü toplumsal kategori olarak kullanilabilmektedir. Bir yandan özel kamusal etkinliklere katılan herkesi tanımlamak için veya 'okuyan kamu' denildiğinde ortaya çıkan ifade biçimlerindeki gibi sınırlı anlamlarda kullanırken, diğer yandan vatandaşların oluşturduğu grubu nitelendirmek için daha geniş anlamda da kullanılmaktadır.

Dördüncü ve son olarak, günün meseleleri üzerine kamusal vatandaşlar arasında oluşan bireysel görüşlerin toplamı 'kamuoyu' şeklinde tanımlanmaktadır.

Bu kısa açıklamadan da anlaşıldığı üzere, kamu/kamusal tanımı ile ilgili çok farklı görüşler mevcuttur. Postmodernist olmasının yanı sıra, Habermas'ın birçok konuda karşı kanıt ürettiği bir düşünür olarak Charles Taylor'un kamusal tanımlaması ve aslında bu tanımla bir karşı görüş dile getirmesi konuya ilişkin farklı düşünüşleri görmek açısından anlamlı olacaktır. Taylor, kamu sözcügünü iki temel anlamda kullanmaktadır: Birincisi, "bütün topluluğu etkileyen işler veya bu işlerin yürütülmesi ile ilgili olma" manasındadır. İkinci anlamıyla kamusalık herkesi kapsayan bir geçiş yetkisini içermektedir; kamuya açı toplantılar, kamuya açı parklar gibi. Veya bir şeyin aleni hâle gelmesini ifade etmektedir; bir haberin kamuya duyurulması gibi (Yükselbaba, 2008, s. 70). Bu kullanımlara göre birincisine 'kamu işleri', ikincisine ise 'kamu otoritesi' örnektir.

"Kamusal alan toplum üyelerinin, matbu veya elektronik çeşitli iletişim araçları sayesinde bir araya gelerek ya da yüz yüze görüşerek kamu yararıyla ilgili konuları tartıştı̆̆ ve böylece bu konular hakkında ortak bir fikir oluşturduğu varsayılan ortak bir mekândır. 'Ortak bir mekân' diyorum, çünkü birçok iletişim aracı ve ortamı olsa da bu ortamlarda birçok mübadele gerçekleşse de ilkesel olarak hepsinin birbirleriyle iletişim içinde oldukları farz edilir. Televizyonda gördüğümüz tartışma bu sabah gazetede ne dendiğini 
dikkate alır, gazetedeki haberse, radyoda dün yayınlanan açık oturumu anlatır vb. Kamusal alanı genellikle tekil kullanmamizın nedeni budur" (Taylor, 2006, s. 89).

Kamusal sözcügünün anlamsal içeriğinin ne olduğu konusunda bir uzlaşmadan bahsetmek gerçekten çok zor. Bu durum tersi açısından da böyle. Bazıları kamusal olanı değil, kamusal olmayanı tanımlayarak kamusal olanı belirlemeye çalışmışlar, fakat karmaşa orada da devam etmiştir. Kamusal olanın ne olmadığı sorusuna verilen cevaplarda iki özellik dikkat çekmektedir. Devlet, çoğu zaman zannedildiğinin aksine, kamusal alandaki aktörlerden biri değildir. Kamu ile devletin zaman zaman özdeş görülmesi devletin kamusal alanın baş aktörü gibi algılanmasına yol açabilmektedir. Devlet, esasen, kamusal alanın koşullarını, altyapısını sağlama hizmetini gören bir araçtır. İkinci özellik ise kamusal alanın, "ücretli işin resmi ekonomik alanı" olmadığıdır (Karadağ, 2006, s. 45).

\section{Kamusal-Özel Alan İlişkisi ve Farklılığ1}

Kamusal-özel alan ayrımı, iki alan arasında gerçekleşen bir karşıtlık ilişkisine dayanmaktadır. Bu iki kavramı analitik olarak ayırt etmek için iki temel ölçüt tespit edilebilir: Birincisi 'görünürlük'tür. Bununla 'açı olan', 'ortaya çıarılan', 'alenileșen' ya da 'erişilebilir olan' ifade edilir. İkincisi 'kolektiflik'tir. Kollektiflik, 'bireysel olan' ya da 'bireye ilişkin olan' veya 'toplumsal olan' ile 'toplumsal yarara yönelik olan' arasındaki ayrımı ifade etmektedir. Bunlar kamusal alanla özel alan ayrımını netleştirmekle birlikte, kamusal ile özel alan zaman zaman iç içe geçebilmekte, ya da ikisi birbirinden farklı boyutlara ve anlamlara göre değerlendirilebilmektedir. Bu kamusal-özel ayrımında çok çeşitli ölçütler bulunduğunun önemli bir göstergesidir (Mahçupyan, 1999, s.24). Weintraub, toplumsal ve politik analizde kullanılan özel/kamusal ayrımını yapan dört model öne sürmüştür:

1. Liberal ekonomist model: $\mathrm{Bu}$ model ile güncel olarak kullanılan en yaygın ayrımı yapılmakta; devlet idaresi ile pazar ekonomisi arasındaki ayrımın kamu ve özele denk düştüğü ifade edilmektedir.

2. Cumburiyetçi erdem modeli: Kökleri Antik Yunan'a dayandırılan bu modele göre, kamusal alan, devlet idaresinden ve pazar ekonomisinden ayrı topluluk ve yurttaşlık alanıdır. Özel alan ise ailenin ve ekonominin alanıdır. Kamusal alan, politikanın alanıdır ve yurttaşların özyönetimini ifade etmektedir. Birinci modelde ise kamusal alan devleti ve onun idaresini ifade etmektedir.

3. Sosyallik modeli: $\mathrm{Bu}$ modelde kamusal alan, toplumsalın içinde 'planlanmamış' sosyal etkileşime karşılık gelmektedir. Özel, mahremiyet alanını işaret ederken, kamusal ise sosyallik içindeki yaşam alanını ifade etmektedir.

4. Feminist analiz̨lerde kullamilan kamusal/özel ayrrm modeli: Özel alan aile içidir. Evin dışında kalan alan ise kamusal alanı oluşturmaktadır (Özbek, 2004, s. 45, 46).

Toplumsal örgütlenmenin üzerine kurulan kamusal alan-özel alan ayırımı, 17. yüzyıldan bu yana Batı Avrupa siyasal düşüncesinde merkezi bir yer tutmaktadır. Bu sözcük ikilisinin tekabül ettiği iki ayırım: Devletin alanı-toplumun alanı, ev alanı-ev dışı alan şeklindedir. Devlet, kamusal alan; ev, aile ve mahrem hayat ise özel alan sayılmaktadır. Bu iki ayırım arasındaki farkın sosyo-ekonomik alanda ortaya çıktı̆ı görülmektedir. Bütün bir düşünce tarihinin üzerine oturduğu bu önemli iki alanda farklı kurallar seti kullanılmaktadır. Özel alan informel ilişkilerin, duyguların, karşılıksız yardımın alanı iken; kamu alanı şeklî ilişkilerin, adaletin ve akılcıllğın alanı olarak nitelendirilmektedir (Bora, 1997, s. 85, 86). Kamu ve özel karşıtlığının, 17. yüzyıl sonlarında, bugünkü kullanımlarına benzer bir anlam aldığ1 görülmektedir. Bu konu hakkındaki araştırmalarıyla tanınan Richard Sennet'e göre kamusal sözcüğ̈̈, "herkesin denetimine açık olan" anlamına gelirken; özel sözcügü "kişinin ailesi ve arkadaşları ile sınırlanan mahfuz bir yaşam bölgesi" anlamına gelmektedir (Sennet, 1996, s. 31). Sennet, kamusal ve özel ifade tarzlarının birbiriyle çelişen şeyler olmaktan çok, birbirinin alternatifi olduklarını dile getirmiştir (Sennet, 1996, s. 131). Bu iki kavramı devlet bağlamında ele alan Althusser (2015), devletin ideolojik aygttlarından olduğunu belirttiği iletişim ve medya aygtlarının büyük oranda özel alanda bulunduğunu belirtir.

Burjuva sınıfının kamusal alan karşısındaki durumu, bazı araştırmacılara göre 'özel alanı' inşa etmeyi gerektirmiştir. Bu bazı araştırmacılar, 'özel alan’ veya ‘özel hayat’ teriminin tarihi süreç içerisinde burjuva sınıfı tarafından sahip olunan ayrıcalıkların geniş halk kitleleri tarafindan fark edilmesinin engellenmesi amacıyla ortaya atıldığını iddia etmektedirler (Danışman, 1991, s. 1). Bu bağlamda Althusser de (2015) hakim sınıfin ideolojik aygıtlar üzerinden özel alanı da kontrol ettiği görüşündedir. Diğger bazılarına göre ise 'özel alan' veya 'özel hayat' kent yaşamının bir ürünü olarak doğmuştur. Toplumu oluşturan insanların önemli bir kısmının yaşadığı kırsal yaşamında hayat olaylarının büyük bölümü herkesin gözü önünde 
olduğundan 'açıklık' söz konusudur; hemen her şey alenidir. Herkes herkesi ve hemen her şeyi bilir. Ancak daha yoğun nüfusun bulunduğu ve bireyin kendisini gizlemek zorunda kaldığı kent yaşamlarında ise 'gizlilik' esas kabul edilmiştir (Philippe, Duby, 2008, s. 164). Özellikle 17. yüzyıldan itibaren geniş halk kitlelerinin kentlerde yaşamaya başlaması ile birlikte, insanlar birbirlerine daha çok yakınlaşmış ve bu yakınlık sayesinde birbirlerini daha kolay takip edebilme imkânı elde etmişlerdir (Zafer, 2010, s. 6). Burjuvazi, öncelikle bireyi, birey de toplum içinde başkalarının meraklı bakışlarından uzak yaşama isteğini ön plana çıkararak, bir bakıma özel hayat ve özel hayatın gizliliği kavramlarının doğumuna öncülük etmiştir (Öncü, 2011, s. 83). Burada özel alan veya özel hayat "kamunun dışında olan, kamusal olana dâhil olmayan" manasındadır. Kamusal olanın açık/aleni olmasına karşılık özel alan/hayat örtük/gizlidir. Bireyin belirli kişiler hariç kamuyu teşkil eden diğer bireylerden gizli tutmak istediği veya yine kendisine yakın buldukları hariç başkalarınca bilinmesini uygun görmediği, sadece kendisinin seçtiği sınırlı sayıdaki kişilerle ve sınırlı ölçüde paylaştığı her türlü yaşam olaylarının oluşturduğu hayat alanı kişinin özel hayat alanını ifade etmektedir (Araslı, 1979, s. 5). Bir başka tanıma göre ise "kişinin dış dünya ile ilişkisinin algılandığı, bilgi, görgü ve verilerin depolanarak sadece sahibi veya kendine yakın birkaç kişinin bildiği, insanın orada daha özgür olduğu bir hayattrr" (Soyaslan, 2012, s. 329).

Günümüzde kamusal alan ilkesi hem mekân hem de anlam (kavram) olarak değişiklik göstermektedir. Kamusal alanın gelişimi erken dönemde kahvehanelerde, kasaba toplantılarında ve edebiyat çevrelerinde başlamıştır. Bu durum günümüzde yerini birçok yerel mekâna bırakmıştır. Geçen yüzyılların yurttaşları söz konusu mekânlarda neyin, nasıl ve ne zaman yapılması gerektiği konusunda tartısmaktaydılar (Keane, 2002, s. 311). Bu tartışmalar artık daha çok televizyon ekranında gerçekleşiyor. Fakat yine de bu tartışmaların birçoğunun televizyonlardaki programlarda gerçekleşiyor olması kamusal alan sözcü̆günün birinci anlamını yitirdiğini göstermemektedir. 'Kamu' sözcüğü, özel olarak bize ait olandan ayrı, hepimiz için ortak olan bir dünyayı ifade etmektedir. Fakat bu dünya, insanların üzerinde hareket ettikleri yeryüzü ya da doğadan farklıdır. Kamusal dünya, yeryüzünde birlikte yaşayan insanlar arasında olup biten meselelerle olduğu kadar, insanın yaptıklarıyla da ilintilidir. Bu dünyada bir arada yaşamak, Arendt'e göre özünde şu anlama gelmektedir:

"Şeylerden oluşma bir dünya, çevresinde oturmakta olanlar tarafindan ortak sahiplenilmekte olan bir masa gibidir, arada olan her şey gibi bu dünya da insanları hem birbirlerine bağlar hem de ayırır" (Arendt, 2006, s. 95, 96).

'Özelin kamusallaşması', 'kamusalın çözülüşü, çöküşü veya dönüşümü', 'toplumsalın sökümü’ gibi argümanlarla tartışlan özel alanın kamusal alana dönüşüm süreci, aslında toplumun cemaatlere ve bireylere kadar parçalanmasının ifadesi olarak anlam kazanmaktadır. Yaşanan bu süreç aynı zamanda ev halkının güvenliğini de sosyal devletin üstlendiği bir iş olmaktan çıkararak, öznelerin kişisel becerilerine bırakmaya soyunmuştur (Sancar, 2002, s. 3). Richard Sennet'in de Kamusal İnsanm Çökü̈s̈̈̈ eserinde bahsettiği gibi, kamusal mekânlar, birbirleriyle herhangi bir bağa sahip olmayan bireyler açısından artık sadece tüketilen, geçilip gidilen mekânlar olarak algılanmaktadır. İnsanlar birbirinden yalıtılmış binalarda yaşamakta ve işyerleri aynı yalıtılmışlı̆ı üretmektedir. Sonuç olarak toplumun paylaştığı ortak alanlar kişinin başkalarıyla bir şeyler paylaşabildiği ortak mekânlar olma özelliğini yitirmiştir. İnsanlar sokaklardan geçmektedir ve içinden geçtikleri mekân, kendilerine son derece yabancilarla dolu bir sahadır (Sennet, 1996, s. 40). Son zamanlarda giderek evin mahremiyeti, toplu mekânların küçümsenmesi, pek çok teknolojik yeniliğin evin yalıtılmışlı̆ına katkıda bulunacak tarzda tasarlanmaları bu amaca yöneliktir. Artık sokaklar, ev ve iş arasında geçilen yabancı mekânlar hâline dönüşmüştür (Çelikoğlu, 2007, s. 28, 29).

Kamusal hayatın karşıtı olarak özel hayatın (İngilizce: private, Fransızcada: prive, Almancada: privat) başlangıcında, mekânsal olarak bir karşıtlık ortaya çıkar. Özel hayatın alanı, evin belirli bir sınırla çevrilmiş alanıdır. Fakat buna rağmen özel hayat alanı sözcügünün anlamı aslında görelidir. Çünkü dıştan içe doğru adım adım ilerlenir. Özel hayatın "aile hayatı; bireysel değil, aile içi ilişkilere ve karşılıklı güvene dayalı bir hayat" (Ariès ve Duby, 2006, 2/, s. 20, 21) şeklinde tanımlandığına da rastlamaktayız. Bundan dolayı özel hayat, aslında ailenin özel hayatı içerisinde kişisel özel hayatı ifade eden bir anlamda da kullanılmaktadır. Feodal Avrupa'da, aile fertlerini yemek ve sohbet için bir araya toplayan ailede herkesin bir görevi vardı. İşlerde görülen bu çeşitlenme, aile bünyesinde de kişisel gizlilik eğiliminin arttığına dair işaretlerin çoğaldığ1 bir dönemde görülmüştür. Ailenin özel hayatı, kişisel özel hayata çerçeve teşkil etmekteydi. Bu ihtiyacı özel alanların düzenlenişinden ve kullanımından anlıyoruz. Mesela zaman içerisinde oda sayısının artması, yatak odalarının kapılarının kilitlenmesi gibi pratikler bu durumu açıkça gözler önüne sermektedir (Ariès ve Duby, 2006, 2/, s. 225). 
Özel hayat sözcüğü standart ve sabit bir anlamı işaret etmediğinden, tanımlanması oldukça güçtür. Çünkü her şeyden önce bu sözcüğün anlam sınırlarını tayin edebilecek, herkesin üzerinde uzlaştı̆̆ ortak ve kesin ölçütler mevcut değildir. Avrupa Insan Haklar Sözlesmesinnde ve AİHM kararlarında da özel hayat sözcügünün tanımının yapılmamış olması dikkat çekicidir. AİHM'e göre, özel hayat bütün unsurlarıyla tanımlanamayacak kadar geniş anlamlı bir sözcüktür (Kilkelly, 2001, s. 16). Ancak, Avrupa Konseyi Parlamenterler Danışma Asamblesinin 428 (19709) saylı kararında, özel hayat, "zorunlu olarak bireyin kendi hayatını en az müdahale ile yaşamasını içerir: özel, aile ve ev hayatı, fiziksel ve moral bütünlüğü, onuru ve şöhreti, aldatılma durumunda olmaktan sakınmak, ilgisiz ve utandırıcı gerçeklerin açılanmaması, özel fotoğrafların izinsiz yayınlanmaması, güvenilerek verilen veya alınan enformasyonun açıklanmasının engellenmesi’’ biçiminde tanımlanmıştır (Üzeltürk, 2004, s. 168). 'Özel hayat' sözcügü özünde muğlakliğ1 barındırdığından, 'Özel ve kamusal olan nedir?', 'Bir eylem hangi noktadan sonra özel alandan çıkıp kamusal alana girer?' sorularına kesin cevaplar bulmak ne öğretide ne uygulamada kolay değildir. Buna ek olarak özel hayat sözcüğünün anlam alanı zamana, mekâna, topluma ve kişiye göre değişebilir özellik taşıdı̆̆ından, sözcügün anlam içeriğini tartsşmaya yer bırakmayacak ölçüde açık ve kesin şekilde tespit etmek şimdiye kadar mümkün olmamıştır. Belki de bu nedenle öğretide bu hak 'özel hayata sayg1 gösterme hakkı', 'özel hayatın gizliliğine sayg1', 'özel hayatın gizliliği hakkı', 'özel hayatın gizliliği ve korunması hakkı' gibi farklı isimler kullanılarak tanımlanmaya çalışılmıştır (Yıldırım, 2004, s. 392; Yüksel, 2012, s. 35-49; Arasli, 1979, s. 43; Şen, 1996, s. 8; Keklik, 2012, s. 8-9).

Uluslararası hukukta 'özel hayat' ilk kez İnsan Haklar Evrensel Beyannamesi’nin 12. maddesinde "Hiç kimse özel hayatı, ailesi, meskeni veya yazışması hususlarında keyfi karısmalara, şeref ve şöhretine karşı tecavüzlere maruz bırakılamaz. Herkesin bu karışma ve tecavüzlere karşı kanun ile korunmaya hakkı vardır" şeklinde düzenlenmiştir. Bu beyannamede yer alan hakların her yerde ve etkin olarak tanınmasını ve uygulanmasını sağlamayı hedef alan İnsan Haklar ve Temel Özgürlüklerinin Korunmasma İliskin Sözleşme'de (Avrupa İnsan Hakları Sözleşmesi) özel hayatın korunması hakkını 8. maddede "Özel Hayatın ve Aile Hayatının Korunması" adı altında; "Herkes özel ve aile hayatına, konutuna ve haberleşmesine saygı gösterilmesi hakkına sahiptir" diyerek düzenlemiştir. Ayrıca Medeni ve Siyasi Haklara İliskin Milletlerarast Sözleşme'nin 17/1. maddesinde de özel hayat sözcügüne yer verilmiştir. Bu sözleşmelerde 'özel hayat' sözcügüne yüklenen anlamla birlikte aile hayatını, meskeni ve haberleşme hakkını koruma altına aldığ1 görülmektedir (Polater, 2010, s. 7). 1967 tarihinde düzenlenen Kuzey Ülkeleri Hukukçular Kongresi’nde varılan sonuçlara göre özel hayatın gizliliği ve korunması hakkı daha geniş değişiyle bireyin aşağıda belirtilen unsurlara karşı korunarak dilediği gibi yaşaması şeklinde belirtilmiştir. Ulaşılan görüşş şudur: Özel, ailevi ve ev hayatına her müdahale; Şeref ve üne zarar vermek; Fiziki ve fikri bütünlüğe veya ahlaki veya entelektüel özgürlüğe karşı bütün tecavüzler; Söz veya fiillerine zarar verebilecek her yorum; Özel hayata ilişkin, konuşma dışı olan ve bireyi zor duruma düşürebilecek olayların açığa vurulması; Bireyin adının, kimliğinin veya görüntüsünün kullanılması; Bireyi casus gibi izlemek, gözetlemek, kollamak ve taciz etmek; Muhabere gönderilerini ele geçirmek; Sözlü veya yazılı muharebeyi kötü amaçılı kullanmak; Bireye iletilen veya bireyin elde ettiği mesleki sırların açığa vurulması gibi durumlar bizzat kişinin özel hayatını ihlal etmektedir (Danışman, 1991, s. 11).

\section{Özel Alan ve Gizlilik İlkesi}

Fransa'da 'özel hayat' sözcügü ilk defa 1819 yılında Basın Kanunu’nun Meclis'teki müzakeresi sırasında kullanılmıştır. Özel hayatın gizliliği konusunu hukuk literatürüne taşıyan ilk yazılı çalışma 1890 yılında Harvard Hukuk Dergisi'nde yayınlanan Samuel D. Warren-Louis D. Brandeis tarafindan kaleme alınmış olan bir makaledir. Makalede özel hayatın gizliliği durumunu karşılamak üzere the right to privacy sözcüğü kullanılmış ve bu hak en basit hâliyle "yalnız bırakılma hakkı" (the right to be let alone) olarak özetlenmiştir (Gökçe, 2016, s. 12, 13). 'Özel hayat' ve 'özel hayatın gizliliği hakkı' sözcüklerinin birbirinden farklı anlamları ifade ettiğini unutmamak gerekmektedir. Özel hayat bir hak değildir, yalnızca bireyin yaşamının önemli bir bölümünü ifade eden bir olgudur. Buna karşın 'özel hayatın gizliliği’ bir hak olup, bu hak 'özel hayat'in hukuken korunmasını amaçlamaktadır. Yasalar çoğu zaman özel hayatın ne olduğunu ayrıntılı bir şekilde tanımlamazlar ya da sınırlarını belirlemezler, sadece bu sözcügü kullanarak özel hayatın gizliliğini koruma altına alırlar. Felsefi alanda epeyce tartısılmış olan özel hayat ile aleni ve genel hayatı ifade eden kamu hayatının kapsamı ve sınırlarının bilinmezlĭgi, varlığını bugün de sürdürmektedir. Çağdaş teoride, özel hayat kamusal olmayan alan tanımından çok daha fazlasını ifade etmektedir. Çünkü kişisel seçimler kişisel bilgilerin korunmasından, malvarlığına ve fiziksel ve zihinsel yaşam alanlarına kadar farklı ve geniş bir alana yayılmıştır (Kaboğlu, 2013, s. 13; Akyürek, 2011, s. 21). Araslı’ya göre özel hayatın gizliliği hakk1; "özel yaşamı düzenlemek, bu yaşamı kimlerin, ne zaman, nasıl ve ne ölçüde 
algılayabileceğine ve bu yaşama müdahale edebileceğine karar vermek ve başkalarının da bu karara sayg1 göstermesini istemek konusunda kişiye, hukuk kurallarınca tanınmış bir yetkidir” (Araslı, 1979, s. 44). Şen ise, 'özel hayatın gizliliği’ ve 'özel hayatın korunması' sözcüklerinin tek başına kullanılması hâlinde konuyu tam olarak ifade etmede yetersiz kalacağından hareketle, ‘özel hayatın gizliliği ve korunması’ sözcügünü bir bütün olarak kullanmayı tercih etmiştir. Söz konusu sözcügü "bireyin kişiliğini geliştirmek ve manevi değerlerine güvence sağlamak için başkaları tarafindan bilinmesini istemediği hususların oluşturulduğu ve korunması hukuken gerekli görülen hayat üzerindeki hakkı" (Şen, 1996, s. 8) olarak tanımlamıştır.

Bireyler bizzat kendi varlıklarına ve yaşamlarına ait durum ve konuları doğal olarak herkesle ve aynı ölçüde paylaşmazlar. Bu duruma bağlı olarak muhataplara göre değişen farklı kategorileri oluşur ve oluşan katmanlara göre ilişki biçimleri geliştirilir. Örneğin özellikle hukukta bireysel hayata ilişkin belirlenmiş farklı katmanlar oldukça önemli ve işlevseldir. Bunlar üç ayrı katmandır. Hukuk terminolojisinde geçerli olan söz konusu katmanlardan birincisi bireyin 'gizli (sır) hayatını', ikincisi 'özel hayatını' ve üçüncüsü ise 'genel hayatını' ifade etmektedir. Söz konusu üç katmanın biraz daha detaylı olmak üzere açılımları şu şekildedir:

Giə̌lli hayat alanı bireyin sadece kendisi için saklı tuttuğu veya kimseyle paylaşmadığı yahut son derece sınırlı sayıdaki bazı kişiler (ailesi, akrabaları, arkadaşları vb.) dışında herkese kapalı tuttuğu durum ve özelliklerini ifade etmektedir. Bu alan kişisel sırları kapsamaktadır. Kişinin cinsel hayatı, bedeninin bazı özel bölgeleri, bazı duyguları, bazı düşünceleri, bazı inançları, bazı ümitleri, bazı korkuları, bazı aile ilişskileri, bazı kişisel ilişsileri, sağlık ve iletişim gibi bazı yaşam olayları bu alanın en önemli unsurları arasındadır (Serdar, 1999, s. 41; Helvac1, 2012, s. 125; Yüksel, 2012, s. 188).

Özel hayat alam bireyin gizli hayatına dâhil olmayan ancak herkese de (topluma/kamuya) açık olmayan, aile üyeleri, yakın arkadaşları gibi sınırlı sayıdaki kişilerle paylaştığı durum, özellik ve olayları içine almaktadır. 'Özel hayat', bireyin kendi öz varlığı ile bütünleşebileceği, dış etkilerden uzak bir bölgeyi ifade etmektedir. Kişi bu alandaki bazı özel yaşam olaylarını kendisine yakın hissettiği sınırlı sayıdaki kişilerle paylaşır. Bu alan, bireyin izni olmaksızın bir başkasının dâhil olamayacağı, bir başkasının bilmesinin arzu edilmediği, toplumun iyi ya da kötü değerlendirmesiyle karşılaşmak istenmeyen, başkalarıyla paylaşmak arzusu taşınmayan yaşam olaylarını içine alır (Helvacı, 2012, s. 125; Tandoğan, 1963, s. 7; Dural, Öğüz, 2004, s. 5; Zafer, 2010, s. 12-13). Hukukçular bu alanı "kişinin özünde tasarruf hakkına sahip olması nedeniyle basskaları tarafindan bilinmesini istemediği ve hukuk tarafından gizliliği ve korunması temel bir şahsiyet hakk1 olarak kabul edilmiş faaliyetler alanı" (Şen, 1996, s. 213-229) olarak tanımlamaktadırlar. Kişinin 'gizli hayat alanı' ile 'özel hayat alanı'nı birbirinden kesin çizgilerle ayırmak güçtür. Ancak gizli hayat alanı, özel hayat alanının hiçbir şekilde dokunulamayan çekirdek kısmını oluşturmaktadır. Örneğin kişinin evinde banyo yaparken izlenmesi ya da görüntüsünün kaydedilmesi yaşamın gizli alanına yönelik bir müdahaledir. Yine aynı şekilde vücudunun özel/gizli/sır bölgelerinin bir şekilde görülmesi gizli hayat alanına müdahaledir. Buna karşılık bireyin evinin korunaklı bahçesinde oturması sırasında gizlice izlenmesi ya da kayda alınması özel hayat alanına yönelik bir müdahaleden bahsedilmektedir (Zafer, 2010, s. 190).

Ortak yaşam alamı, bireyin başkalarının bilmesinde sakınca görmediği yaşam olaylarını ifade etmektedir. Kural olarak kişinin ortak yaşam (topluma/kamuya açı) alanında iken başkalarının kendisini izlemesine, dinlemesine ya da gözlemlemesine örtülü olarak izin verdiği kabul edildiğinden herkesin gözü ününde gerçekleşen bu yaşam olaylarına başkalarının algılarına da açık olacaktır. Buradan hareketle kamuya açı alan, önceden belli ve sınırlı olmayan sayıdaki kişilere açık, başkalarının görmesine, duymasına veya izlemesine elverişli yaşam alanlarının tamamını ifade etmektedir. Bireyler bu ortak alanda yaptığ faaliyetler ve görünen aleni işlemlerden dolayı herhangi bir rahatsızlık duymazlar. İnsanoğlunun yaratılışından beri ortak yaşam alanları mevcut olup, köylerde meydanlar, şehirlerde parklar, alısveriş merkezleri, cadde ve sokaklar olarak örneklenebilir. Kamuya açık alanlarda kural olarak özel hayatın gizliliği hakkı en asgari düzeyde korunur. Kişilerin rızalarına aykırı olarak resimlerinin çekilmesi ya da ses veya görüntüsünün kaydedilmesi hâlinde özel hayatın gizliliği hakkının ihlali söz konusu olabilir (Polater, 2010, s. 6; Çelebi, 1997, s. 273; Helvac1, 2013, s. 136-138).

\section{Özel Alanın Gözetim Nesnesine Dönüşümü ve Sosyal Medya}

Filozof Herakleitos 'Her şey değişir' derken içinde yaşadığı fizik dünyaya ve insanların yaşam tarzlarına bakmış olmalı. Daha çok da fizik dünyadaki oluşum ve değişimleri öncelemiş olmalı ki, kuramına ilişkin örneğini 'nehir', 'su', 'yıkanmak' gibi sözcükler üzerinden ve tamamıyla nesnel dünya ile ilgili alandan vermiştir. Herakleitos acaba zamanımızda yaşasaydı, teknolojinin ve yaşam tarzlarının birbirlerini karşılıklı değiştirme güç ve hızlarını görseydi ne düşünürdü? 'Değişimden başka her şeyin değiştiği’ görüşünün 
sarsılmaz bir inanca dönüşeceğinde kuşku yok. Özellikle de 'değişim' denen şeyin, ontolojinin ve epistemolojinin en temel unsuru olduğunu daha büyük özgüvenle dile getireceği kesin. Çünkü teknolojizihniyet-yaşam tarzı arasında gerçekleşen karşılıklı etkileşim ve bu etkileşime bağlı olarak gerçekleşen değişim ve yeni durumların oluşumu o kadar hızlı ki takibi bile zorlaştı. Bilgisiyle ve yaşam tarzıyla mevcut olanla yetinip yenileri alma/içselleştirme sürecine girmeden biraz soluklanmak için duranlar, her geçen gün ivmesi daha da artan sürece dâhil olduklarında çok şeyde gerilerde kaldıklarını, adeta terkedilmiş bir dünyanın mensubu hâline dönüştüklerini fark ediyorlar.

$\mathrm{Bu}$ tespiti iletişim teknolojileri ve iletişim süreçleri açısından irdelemek gerekirse; kitle iletişiminin temel işlevlerini 'bilgi verme', 'toplumsallaştırma', 'güdüleme', 'tartışma', 'eğitim', 'kültürlendirme', 'eğlendirme' ve 'katılım sağlama' oluşturmaktadır. Genel olarak iletişimde, özel olarak da kitle iletişiminde gerçekleşen değişimin düzeyini ve kapsamını görebilmek için kitle iletişiminin işlevinde gerçekleşen değişim dikkate alınabilir. Hızla gelişen ve daha da önemlisi ucuzlayan iletişim teknolojileri bireylerin bireysel ve toplumsal yaşantısını hızla değiştirmiştir. Üstelik hala da değiştirmeye devam etmektedir. $\mathrm{Bu}$ bakımdan günümüzde yaygın olarak kullanılan ve hatta diğer iletişim araçlarını kullanım yoğunluğu açısından geride bırakmış olan sosyal medya oldukça önemli bir konumdadır. Konuyu akademik bir yaklaşımla ele alan, inceleyen, araştıran hemen herkesin sıklıkla ifade ettiği üzere, sosyal medya, bireylerin ekonomik, siyasi ve kültürel anlayışlarını; olay ve durumları değerlendiriş tarzlarını; tutum ve davranışlarını; bireysel ve toplumsal yaşantılarını değiştirme ve dönüştürmede oldukça güçlü etkilere sahip durumdadır. Lyon'a göre (2012, s. 197), gözetim eksenli bir dünyada yaşıyoruz ve bu dünyada 'görünmez' olmak giderek daha da zorlaşmaktadır. Panoptikon'un sibermekâna taşınmış güncel bir versiyonu olarak elektronik veritabanı üzerinde yazdığı denemede Mark Poster, "bedenlerimizin şebekeler, veritabanları, enformasyon koridorları içine çekildiğini" ileri sürmüş ve bu sebeple bedenlerimizin "enformatik olarak bağlandığı" bu enformasyon depolayan yerlerden hiçbiri "artık gözlenmekten kaçabileceğimiz ya da etrafına direniş hattı çekebileceğimiz bir sığınak sağlamamaktadır”" tespitinde bulunmuştur. Her bir kredi kartı kullanımı ve hemen her bir satın alma eylemiyle çoğalan muazzam miktardaki veri, Poster'e göre bir süperpanoptikonla sonuçlanıyor. Süperpanoptikonun panoptikondan tek fark1, depoya veri sağlayan gözetim altındakilerin, gözetimin birincil ve gönüllü unsuru olmalandır (Bauman, 2006, s. 60).

Verilerin ticari bir metaya dönüştüğü günümüzde, dijital iletişim araçlarının kullanılarak yapılan tüm hareketler kayıt altına alınmaktadır. Bu durum bir distopya gibi görünse de aslında günümüzün gerçeğidir. Gerçekleşen gözetleme sadece bireyler üzerinde uygulanan bir sistem olarak ele almak doğru değildir. İki düzeyde gerçekleşen gözetleme söz konusudur. Bunlar "makro düzey” ve "mikro düzey” gözetlemelerdir. Gözetlemenin makro ve mikro düzeyi arasındaki en önemli ayrım 'rıza' ile ilgilidir. Gözetlemenin mikro düzeyinde bireyin rızası varken ve hatta buna gönüllü olurken, makro düzeyde rıza genelde yoktur. Makro gözetlemede gözetlenen rıza göstermeden gözetlemenin nesnesi hâline dönüşmektedir. Ayrıca mikro gözetlemede bireyler birbirlerini karşılıklı olarak gözetlerler, buna 'gözetişim' ya da 'simetrik gözetleme' denilmektedir. "Güvenlikleştirilen toplumda iki tür dramatis personae vardır: mahpuslar ve gardiyanlar. Ve sizden iki rolü birden aynı anda oynamanız istenir” (Hardt, Negri, 2013, s. 27). İște 'gözetişim’ ya da 'simetrik gözetleme' hem mahpus hem de gardiyan olunan bir düzenin isimleri olarak anlam kazanmaktadır. Makro düzey oldukça geniş bir alanı ifade etmektedir. Makro düzeyde gerçekleşen gözetlemenin unsurları şunlardır: 'Diplomatik gözetleme' (devletlerin birbirlerini gözetlemeleri), 'bürokratik gözetleme' (devletin kendi içinde kendini gözetlemesi), 'kamu gözetlemesi' (devletlerin vatandaşlarını gözetlemeleri), 'otoriteyi gözetleme' (vatandaşların devleti gözetlemeleri), 'kapitalist gözetleme' (ticari işletmelerin bireyleri gözetlemeleri). Kamu gözetlemesi olarak anılacak olan devletlerin vatandaşlarını gözetlemesi, modern toplumlarda en alışıldık olunan gözetleme sistemlerinden birisidir. Devletler vatandaşlarını hem 'gözetmek' için hem de 'gözetlemek' için izlerler. Diğer bir ifadeyle devlet hem kendi vatandaşlarını suç işlemesinler diye gözetler, hem de vatandaşlarının 'güvenliğ̣i için vatandaşlarını gözetir. Çünkü "iktidar açısından kendi halkları potansiyel teröristtirler” (Baudrillard, 2012, s. 114).

Devletlerin vatandaşları gözetlemesini iki açıdan ele almak mümkündür: Birincisi rıza üreterek (aleni) gözetleme, diğeri ise rıza üretmeden (gizli) gözetleme. Günlük hayatta karşılaşılan ve devlete ait kurumlar tarafından yerleştirilmiş olan kameralardan, pasaportlara, hastane kayıtlarından, ikamete kadar pek çok bilgi devletin vatandaşlarını gözetleme yollarındandır. Sayılan gözetleme yollarından hastane kaydı, ikamet, pasaport gibi örneklerinde olduğu üzere bir kısmı için vatandaşlar bunun bir gözetleme sistemi olduğunu dahi akıllarına getirmezler; onlar kanıksanmış ve artık sorgulamaktan çıkmıştır. Güvenlik kameraları için ise rıza üretilmiştir, özellikle suçluların tespiti ve suç işlemenin caydırıcı unsuru olarak işlev gördükleri 
noktasında yoğun bir ikna süreci işletilmektedir. Bu sebeple de vatandaşlar güvenlik kameralarından herhangi bir rahatsızlık duymamaktadır, aksine kameralar onlara 'güven' vermektedir. Devletin rıza üretmeden yaptığ gözetlemeler ise telefon dinlemeleri, maillerin izlenmesi gibi faaliyetlerdir. Dinlenme ve izlenme saplantısı paranoid özellikler gösteren toplum olma yolunu açmıştır. Bu gözetleme biçimi gizlidir; çünkü vatandaşlar kendilerinin gözetlendiğinden şüphe etseler bile gözetlenip gözetlenmediklerini bilmezler, bilemezler; bu bir anlamda panoptikondur. Bir gözetleyenin olduğu bilinir ama gözetleyenin gözlerinin kendi üzerinde olup olmadığı belirsizdir. Yapılan resmî açıklamalar toplumun endişelerini haklı çıkarır niteliktedir.

Mikro düzey gözetleme sosyal ağları kullanan bireylerin birbirlerini gözetlemelerini ifade etmektedir. Mikro düzey gözetlemede dijital iletişim ağına katılmış olan kullanıcılar başka kullanıcıları gözetleyebilirler. Aynı şekilde diğer kullanıcılar tarafından da kendileri gözetlenmeye açıktırlar ve bunu kabullenmiştirler. Başka kullanıcıların kendisini ne kadar gözetleyebileceğini ise sitenin sunduğu güvenlik ayarları ile belirlemek mümkündür. Mikro düzey gözetleme çerçevesinde önemli olan kullanıcıların birbirlerini karşıllklı gözetlemeleridir ve bu kabul edilmiş bir gözetlemedir, dolayısıyla meşrudur. Günümüzde internetin yaygınlaşmasıyla birlikte panoptikon ve sinoptikon yerini omniptikon'a bırakmıstır. Artık çoğunluğun birbirini izlediği bir gözetim süreci söz konusudur. Burada da sosyal paylaşım ağları olan Facebook, Twitter gibi araçlar üzerinden insanların birbirlerinin yaşamlarını gözetlemek altında tuttuğu görülmektedir (Toktaş, Binark, Dikmen, 2012, s. 33).

"Görünür olma talebi ile birlikte gözetlenmeye izin verme bireyin yaşamını kendi talebi ile kamusal alana açması ve bu da sosyalleşme, sosyal sermaye gibi gururla (!) taşıyor olması yaşamımıza sosyal medya ile yoğun bir şekilde yer alıyor" (Rigel, 2014, s. 891).

Kullanıcılar sosyal medyada gözetlenmek ve gözetlemek için yer alırlar. Yaptıkları 'paylaşımların' 'beğeni alması', 'yorum yapılması', 'retweet' edilmesi ya da 'favorilere eklenmesi' kullanıc1yı memnun eder, görünür olduğunu ve onaylandığını hissettirir, yani gözetleniyor olmak mikro düzey gözetlemede arzu edilen bir şeydir. Aksine gözetlenmiyor olmak, Facebook'ta arkadaş, Twitter'da takipçi sayısının az olması, kullanıcıları mutsuz eder. Kullanıcıların birbirlerini gözetliyor oluşu simetrik gözetleme durumunu ortaya koyar. Yani her gözetleyen aynı zamanda gözetlenen, her gözetlenen ise aynı zamanda gözetleyendir. "Bakanın bakanda aradığı, bakıldığını görmektir" sözü sosyal ağlardaki gözetlenme arzusunu ortaya koymaktadır. Kullanıcılar burada hem gözetlenme nesnesi olurken hem de gözetleyen özne hâline gelirler.

Mikro düzey gözetlemede dijital ă̆ yönetimi bireyleri gözetleyen iradeyi temsil etmektedir. A $\breve{g}$ yönetimi kullanıcıların tamamını gözetleyen, onlardan veri toplayabilen bir erktir ve yaptığı işlem kullanıcıların birbirleriyle yaptığı gözetlemenin tersine asimetrik gözetlemedir; kullanıcılar onu gözetleyemezler, o kullanıcıları gözetler, karşılıklılık esası burada bulunmaz. Kullanıcılar yaptıkları paylaşımlar sırasında asimetrik gözetlemeyi akıllarına getirmezler, onların yaptıkları 'arkadaşlar' ya da 'takipçiler' ile iletişim kurmak adına ileti göndermektir. Oysa asimetrik gözetleme erki her zaman uyanıktır ve sürekli işinin başındadır. Bu noktadan bakıldığında gerek makro düzeyde gerekse mikro düzeyde gerçekleşen gözetlemelerin son noktasında gözetleyici konumda olan gözetlemenin içerik ve sınırlarını belirleyen, gözetlemeyi mümkün kılan ve teknolojiyi elinde bulunduran(lar)dır. Zira bu, kişi veya kurumların devletleri de gözetleyebilme imkânına sahip oldukları söylenebilir.

Özünde varlığının bilinmesi, fark edilmesi, takdir edilmesi, değer verilmesi gibi arzuları olan birey günümüzde bir yandan kamusal alanda yüz-yüze ilişkilerden uzaklaşıp yalnızlaşırken, öte yandan bu arzularını erişebildiği iletişim teknolojisi kaynakları ile tatmin etme sürecini yaşarken aynı zamanda sanal sosyalleşme süreci yaşamakta ve/veya kamusal alana çıkmaktadır. Doğal maddi yaşamda bir başkası ile yüz yüze iletişim kurmak, kendine uygun zaman, mekân, kaynak ve emek gerektirmektedir. Dolayıs1 ile bugünün dünyasında, sosyal medyanın yaygın olarak kullanıldığı bu zamanlarda daha az maliyet ve emekle, zaman ve mekân kısıtı olmaksızın hızlı bir şekilde bu arzuların tatmini sağlanmaya çalışılmaktadır. Ancak bahsedilen arzuların tatmininin ötesine geçen gözetlenme ve gözetleme günümüz sosyal medya ortamında normal kabul edilmektedir. Çünkü bu istek ve rıza ile gerçekleşmektedir. Bu ise bir boyutuyla 'röntgencilik' (voyeurism), bir başka boyutuyla da 'teşhircilik' (exhibitiorizm) olarak boyut kazanmaktadır. Her iki durum da bireylerin kendi hayatlarına ait anları siber uzamda teşhir etmeleri ile gerçekleşmektedir. Teşhirin nedeni gözetlenmeyi, izlenmeyi, dikizlenmeyi kabul etmektir ve hatta bundan memnuniyet duymaktır. İzlenmenin kişiye kendini iyi hissettirdiği bir alg1 tesis edilmiştir. Biri Biæ̌i Gözettliyor yarışmacısı Josh'un dediği gibi artık "herkesin bir izleyeni olmalıdır" (Lyon, 2013, s. 222) yoksa insanlar yalnız ve mutsuz olmaktadırlar. Bu sebeple izlenmek, internette en fazla önem verilen şeylerden birisidir: Bloğınuz. 
kaç kere ziyaret edilmis, Facebook'taki fotoğrafimı̨ kaç kişi 'beğenmiş', Twitter'da kaç tane 'takipsiniz’' varmış, kaç kişi tweetiniz̧i retweet etmiş? Günümüzde bireylerin siber uzamla ilgili en önemsediği sorular bunlar olup çıkmıştır. Demek ki mesele sadece kullanıcıların kendilerini teşhir etmeleri değil, ayrıca teşhir ettiklerinin onaylanması, teşhirin onayı ile görünürlüğün artmasıdır. Teşhirciliğin amacı, ona bakan gözün içindeki boşluğu doldurmak, ama onu bakışla doldurmak, bakışın kendini perdelemektir. Teşhirciliğin yol açtı̆̆ sonuç başkasının bakışında varlığını bulmaktır. Adeta bir hastalık gibi yaygınlaşan teşhir merakı, bireyin izlenmeye ve kendinin önemli olduğuna inanma arzusunun sonucu olarak açığa çıkmaktadır. Nasıl ki magazin programlarında ünlülerin hayatını izlemek insanlara zevk veriyorsa, sanal ortamda tanıdığı kişilerin hayatını hem de eş zamanlı olarak izlemek, izleyene de izlenene de tatmin sağlıyor. Bu bakmanın ve bakılmanın tatmininden başka bir şey olmadığı söylenebilir.

\section{Sonuç}

Kamusal alan olgusu ve konusu hem anlamıyla hem de işlevleriyle, temelde tamamen denecek düzeyde olmak üzere siyaset felsefesinin konusudur. Kamusal alanın yaygın anlamı her ne kadar Habermas'ta ifadesini bulsa ve siyaset felsefesine onun tarafindan hediye edilmiş olsa bile, onun Antik Yunan devletinin (polis) işleyişinde şekillendiği de yaygin bir kabule sahiptir. 'Kamusal alan' ve 'kamuoyu' kavramlarının ilk kez sadece 18. yüzyılda ortaya çıkması hiçbir şekilde bir rastlantı ürünü değildir. Bu kavramlar özgül anlamlarını somut bir tarihsel durumdan alırlar. Bu ise 18. yüzyıl Batı Avrupa'sının sosyal ve siyasal şartlarıdır. Dönemin şartlarında 'kamusal alan' olgusu ve anlayışı oluşurken, aynı zamanda ‘özel alan’ olgusu ve anlayışı da oluşur. Bu da beklendik bir şeydir, çünkü söz konusu her iki olgu ve anlayışın varlığı birbirine bağlıdır; karşlıklı birbirlerini inşa ederler. Bir başka söyleyişe biri olmadan diğeri olmaz.

Kamusal alan ve özel alan olgusu ve anlayışı oluştuğunda, gerçekleşen oluşum sabit kalmamıştır. İnşa süreci günümüze kadar kesintisiz devam etmiş, bu süreçte kamusal ve özel alanın anlamı ve işlevi değişime uğramıştır. Değişimin son yüzyıldaki en önemli aracı televizyon başta olmak üzere kitle iletişim araçları, son 20-30 yıldaki en önemli aracı ise internet ve onun ürünü sosyal medyadır. İnternet teknolojisinin ve özellikle de sosyal medya mecralarının sürece dâhil olmasına kadar özel alanın kamusal alanın lehine daralması dışsal bir güçle gerçekleşirken; bireyler yoğun çabaların sonunda ikna edilerek, motive edilerek ve hatta zorla özel alanlarını daraltmaya ve böylelikle kamusal alanın daha da yaygın, geniş ve güçlü olması sağlanırken artık sürecin işleyiş mantığ1 da değişmiştir. Artık bireyler kendi özellerini kendi elleriyle kamusalın parçası kılmaktadırlar; mahremiyet algısı hızla değişmekte; mahrem olanlar, bireylerin istek ve arzularıyla alenileştirilmektedir.

İletişim teknolojilerinin gelişimine ve özellikle sosyal medyanın yaygınlaşmasına bağı olarak günlük hayattaki mahremiyet anlayışıyla sanal uzamda yaşanan mahremiyet anlayışı gittikçe iç içe geçmiş ve genişlemeye başlamıştır. Arzulanan dünyayı izlemek ve sunmak artık belirlenmiş kodlara göre değil, bireyin bizzat kendisinin belirleyeceği kodlarla gerçekleştirmek mümkün hale gelmiştir. Birey, internet teknolojisi aracıllğ̆ıla kamusal-özel alanı kendine göre yeniden inşa etme ve sınırları ile oynama imkânına sahip olmuştur. Günümüz bireyleri bilgisayarın başında yalnız başına ve tüm gözlerden uzaktayken aynı zamanda istediği anda görünür olup kamusal alana sıçrayabilen geçişler yapabilme imkânına sahiptir. Mahremiyeti kiminle, ne kadar paylaşacağ şimdilik bireyin kendi kontrolünde gibi gözükmekle birlikte, bireyin kendi kontrolü dışında da mahremiyetine sızmalar olduğu bilinmektedir. Mahremiyet ile ilgili bu yeni deneyimin sınırları belirsizdir. Modernliğin etkileriyle kamusal alandan özel alana çekilen ve kendisini birey olarak inşa eden insan, yeni medya ile birlikte özel alandan tekrar kamusal alana çıkmıstır. Bu geriye dönüş modernliğin sınırlarını çizdiği bir kamusal alan / özel alan tanımının ötesine uzanabilecek yeni bir alana işaret etmeye başlamıştır.

\section{Etik Beyan}

"Kamusal-Özel Alan Ayrışmasımn İnşa Süreci ve Sosyal Medya" başlıklı çalışmanın yazım sürecinde bilimsel kurallara, etik ve alıntı kurallarına uyulmuş; toplanan veriler üzerinde herhangi bir tahrifat yapılmamış ve bu çalışma herhangi başka bir akademik yayın ortamına değerlendirme için gönderilmemiştir. $\mathrm{Bu}$ araştırmada doküman incelemesi yapıldığından etik kurul kararı zorunluluğu bulunmamaktadır.

\section{Kaynakça}

Akyürek, G. (2011). Özel hayatın gizliliğini iblal sucu. Ankara: Seçkin Kitabevi.

Althusser, L. (2015). İdeoloji ve devletin ideolojik aygitlan (Çev: A. Tümertekin). İstanbul: İthaki Yayınları.

Araslı, O. (1979). Özel yaşamın gizliliği hakke ve T.C. Anayasasında düzenlenişi. (Doçentlik Tezi). Ankara.

Arendt, H. (2006). Insanlık durumu (Çev: B. S. Şener). İstanbul: İletişim Yayınları. 
Ariès, P. \& Duby, G. (2006). Özel hayatın taribi 2- Feodal Avrupa'dan Rönesans'a (Çev: R. Hamken). İstanbul: Yap1 Kredi Yayınları.

Baudrillard, J. (2012). Şeytana satılan rub - Ya da kötülügün egemenliüi (Çev: O. Adanır). Ankara: Doğu Batı Yayınları.

Bauman, Z. (2006). Küreselleșme - Toplumsal sonuçlar (Çev: A. Yılmaz). İstanbul: Ayrıntı Yayınları.

Bora, A. (1997). Kamusal alan/özel alan: mahrumiyet-özgürleşme ikileminin ötesi. Toplum ve Bilim, 75, 85-93.

Çelebi, F. (1997). Kişilik haklarından kişinin özel yaşamının ve gizliliklerinin ihlali ve korunması. Kocaeli Üniversitesi (KOU) Hukuk Fakültesi Dergisi.(1), 271-296

Çelikoğlu, N. (2007). Türkiye'de üniversite gençliğinde mahremiyetin dönüşümü (Yüksek Lisans Tezi), Marmara Üniversitesi, İstanbul.

Danışman, A. (1991). Ceza bukuku açısından özel hayatın korunması. Konya: Selçuk Üniversitesi Basımevi.

Dural, M. ve Öğüz, T. (2004). Kişiler hukuku. İstanbul: Filiz Kitapevi.

Gökçe, Y. (2016). Özel hayata ve hayatın giz̨li alanına karşı suçar (Doktora Tezi). Ankara Üniversitesi, Ankara.

Gripsrud, J., Hallvard, M., Molander, A. vd. (2010). The ıdea of the public sphere. Polymouth: Lexington Book.

Habermas, J. (1974). The Public Sphere: An Encylopedia Article, New German Critique, 3. 49-55.

Habermas, J. (2005). Kamusallğ̌n yapısal dönüşümü (Çev: T. Bora ve M. Sancar). İstanbul: İletişim Yayınları.

Hardt, M. ve Negri, A. (2013). Duyuru (Çev: A. Yılmaz). İstanbul: Ayrıntı Yayınları.

Helvacı, S. (2012). Gerçek kişiler. İstanbul: Legal Yayıncilık.

Kaboğlu, İ. Ö. (2013). Öqgürlükler bukuku-1. Ankara: İmge Kitabevi.

Karadağ, A. (2006). Postmodernite ve kamusal alan: Mutlak hakikat arayışının sonu. İçinde A. Karadağ (Edt.). Kamusal alan ve Türkiye (ss. 192-209). Ankara: Asil Yayın Dağıtım.

Keane, J. (1984). Public life and late capitalism: Toward a socialist theory of democracy. Cambridge: Cambridge University Press.

Keane, J. (2002). Kamusal alanın yapısal dönüşümleri. İçinde S. İrvan (Der.). Medya kültür siyaset. Ankara: Alp Yayınevi.

Kejanlıŏ̆lu, D. B. (2004). Medya çalışmalarında kamusal alan kavramı. İçinde M. Özbek (Edt.). Kamusal alan (ss. 688713). İstanbul: Hil Yayınlar1.

Keklik, R. (2012). Özel hayatın gizliliğini iblal suçlar. Ankara: Adalet Yayınevi.

Kilkelly, U. (2001). Özel hayata ve aile hayatına saygr gösterilmesi hak.k., Avrupa İnsan Haklar Sözlesmesinin 8. Maddesinin uygulanmasina iliskein kilavuz. Ankara: İnsan Hakları El Kitapları.

Lyon, D. (2012). Vesikah yurttaş-Gǫ̈etim aracı olarak kimlik kartlar (Çev: B. Baysal). İstanbul: Kalkedon Yayıncılık.

Lyon, D. (2013). Gözetim çalsşmalar (Çev: A. Toprak). İstanbul: Kalkedon Yayınları.

Mahçupyan, E. (1999). Osmanlı’dan günümüze parçalı kamusal alan ve siyaset. Doğu Batı. 5.

Malkoç, İ. B. (2018). Siber kamusal alanda metalaşan kimlikler ve otosansür: Twntter örneği (Yüksek Lisans Tezi). İstanbul Ticaret Üniversitesi, İstanbul.

Mutlu, E. (2004). İletişim sözlüğ̈̈. Ankara: Bilim ve Sanat Yayınları.

Onat, N. (2010). Kamusal alan ve sinirlar (Doktora Tezi). Maltepe Üniversitesi, İstanbul.

Öncü, G. A. (2011). Avrupa insan haklar sözleşmesinde özel yaşamın korunması bakke. İstanbul: Beta Yayıncılık.

Özbek, M. (2004). Giriş: Kamusal alanın sınırları. İçinde M. Özbek (Edt.). Kamusal Alan (ss. 19-89). İstanbul: Hil Yayınları.

Philippe, A. ve Duby, G. (2008). Özel hayatın taribi, cilt: 5. İstanbul: YKY.

Polater, Y. Z. (2010). Türk Hukukunda ve Avrupa Insan Haklar Sǫ̈leşmesinde Özel Hayatın Giq̨iliği ve Korunmasi, Ankara: Adalet Yayınevi.

Rigel, N. (2014). İkinci el yaşam: E-hayat. Yeni Türkiye Öz̧el Sayısı, 10, 890-893.

Sancar, N. (2002). Eve ne oldu? Evrensel Kültür, 127, 2-12.

Sennet, R. (1996). Kamusal insanın çöküşü (Çev: S. Durak ve A. Yılmaz). İstanbul: Ayrıntı Yayınları.

Serdar, İ. (1999). Radyo ve televizyon yoluyla kişilik haklarmm iblali ve kişiliğin korunması. Ankara: Seçkin Yayınları.

Soyaslan, D. (2012). Ceza bukuku özel bükümler. Ankara: Yetkin Yayınları.

Şen, E. (1996). Devlet ve kitle iletişim araçlan karşısında özel hayatın giz̨liliği ve korunması. İstanbul: Kazancı Kitap.

Tandoğan, H. (1963). Şahsiyetin akit dışı ihlallere karşı korunmasının işleyiş tarzı ve basın yoluyla olan ihlallere karşı özel hayatın korunmas1. Ankara Üniversitesi Hukuk Fakültesi Dergisi, 20(1), 1-20.

Taylor, C. (2006). Modern toplumsal tahayyüller (Çev: H. Koyukan). İstanbul: Metis Yayınları.

Toktaş, S. A., Binark, M. ve Dikmen, E. Ş. (2012). Türkiye'de dïital göžetim. İstanbul: Alternatif Bilişim Derneği Yayinları.

Türk Tarih Kurumu (1983). Türkşe sö̊lük. Ankara: Türk Tarih Kurumu Basımevi.

Üzeltürk, S. (2004). 1982 anayasası ve insan haklar Avrupa sözleșmesine göre özel hayatın gizliliği hakke. İstanbul: Beta Yayınları.

Yıldırım, G. (2004). Insan haklar Avrupa sözlessmesi ve adli yargı. Ankara: TBB Yayınları.

Yüksel, S. (2012). Özel yaşamın bir parçası olarak telekomünikasyon yoluyla yapulan iletişimin giz̨liliğine önleyici denetimle müdahale. İstanbul: Beta yayınlar1.

Yükselbaba, Ü. (2008). Habermas'da kamusal alan/özel alan ayrmı (Doktora Tezi). İstanbul Üniversitesi, İstanbul.

Zafer, H. (2010). Özel hayatın ve hayatın gizli alammn ceza bukukuyla korunması (TCK m. 132-134). İstanbul: Beta Yayınları, İstanbul. 


\section{EXTENDED ABSTRACT}

The "public sphere", born as the product of the social and political conditions of Western European societies, gained its original form in the 18th century. The conceptual construction of the word 'Public', dating back to Ancient Greece, is based on the lifestyle and social relations that dominate the Hellenistic social structure. Aristotle called the unique life of people as 'home' and he gave the name 'polis' to the area where compulsory social relations required by political life were established. Political debates and exchanges of thought in the agoras known as the discussion halls of the cities in ancient Greece were the beginning of the construction of the 'public'.

The public sphere with its modern meaning and function emerged as a product of the social and political environment of the 18th century Western Europe. In this century, the discussion of political issues in coffee shops, clubs, halls, press and parliament-like places led to the emergence of political public space. With the contribution of the print media industry, these spaces have become the main forums where the government's activities and practices are discussed.

"Public" means in the Turkish dictionary, "1.All, whole 2.All the people in a country" (Turkish Dictionary, 1983, p. 633). "Public space" means with its use in the socio-political sphere "The place where the public authority applies" "the place where pluralism, colority and freedom" and "every place where the public official is". (Yükselbaba, 2008, p.227).

Habermas's determination about the public sphere is as follows: "By the concept of public space, we mean, above all, an area in our social life where something similar to the public opinion can be created. All citizens access to this area is guaranteed... Citizens behave in the form of a public body only when they can discuss unrestricted issues of general interest, that is, their freedom to gather, organize, express their opinions and publish" (Habermas, 2005, p. 95).

According to Arendt, there are two different meanings in the term public space; the first is "made public on" and the second is "the world that is owned jointly". The idea of public space in the sense of "made public on", "Everything known in the public is visible, audible to everyone, and has the widest possible opening." (Arendt, 2006, p. 92).

It is really hard to talk about a compromise on what the semantic content of the public word is. Some try to use the "non-public" to describe the "public", but the confusion has continued there as well.

The area of private life is the area of the house surrounded by a certain limit. The word private life does not indicate a standard and fixed meaning, so it is very difficult to define.

The formation of the 'private space' phenomenon is not independent from the formation of the 'public space' concept. Because the existence of one necessitates the presence of the other. The word "private" refers to a closed living space, namely privacy, limited by the person's family and friends.

The distinction between public and private spaces is based on a contrasting relationship between the two areas. To distinguish these two concepts analytically, two basic criteria can be identified: The first is 'visibility', this mean 'open', 'revealed', 'publicized' or 'accessible'. The second is 'collectivity'. Collectivity refers to 'individual', 'special for person' or the distinction between 'communal' and 'social benefit'. While these clarify the distinction between public and private space, public and private space may intertwine from time to time. This is an important indicator that there are various criteria in the public-private distinction (Mahçupyan, 1999, p. 24).

The development of information and communication technologies has radically changed the private sphere. Change works in favor of the public space, against the private space. Internet technology, especially social media, made public on the ones belonging to the private area and causes this area to shrink every day. Today, this change does not happen with an external intervention as it was in the past, on the contrary, people disclose their own private life.

Communication technologies, which are very cheap nowadays and accessible to almost everyone, rapidly change the individual and social life of individuals. Social media is very important in this technology. Social media, individuals' economic, political and cultural understanding; the way they evaluate events and situations; attitudes and behaviors; it has very strong effects in changing and transforming. The most important feature that distinguishes social media channels and devices from other communication tools is that they can easily access and record all kinds of data belonging to individuals. This is literally a surveillance. 
As Lyon says (2012, p. 197), we live in a world with surveillance axis and it is getting more and more difficult to be 'invisible' in this world. Surveillance takes place at "macro level" and "micro level" The most important distinction between these two levels is related to 'consent'. While at the micro level surveillance, when the individual has consent and even volunteers, macro level consent is generally absent. In micro surveillance, individuals observe each other mutually, this is called "surveillance" or "symmetrical surveillance". It turns into the object of surveillance without showing consent in macro surveillance. The macro level represents a very large area. States are the basis for the surveillance that takes place at the macro level, and they both oversee each other and their citizens.

Micro-level surveillance refers to individuals using social networks to watch each other. Users who have joined the network in micro level surveillance can monitor other users. Likewise, they are open to surveillance by other users and they accept it.

This situation can be carried to a different dimension of 'voyeurism' and 'exhibitionism'. Individuals now display their own special life with their own consent. The perception of privacy is changing rapidly; the confidential ones are exhibited with the wishes and desires of the individuals. At the last point, the content of private area is changing every day in terms of scope narrowing and confidentiality. 